\title{
Well-being and functional abilities in nursing home and home living seniors in Latvia
}

\author{
Aija Balode $^{1}$, Anda Stolarova $^{2}$, Anita Villerusa $^{1}$, and Janis Vetra ${ }^{1}$ \\ ${ }^{1}$ Rīga Stradinsš University, Latvia \\ ${ }^{2}$ University of Latvia, Latvia
}

\begin{abstract}
The society in developed countries is aging. 1.5\% of seniors live in nursing homes in Latvia. Aim: to compare functional abilities and wellbeing between nursing home and home living Latvian seniors. Methods: 280 home living seniors and 285 from nursing homes, age $\geq 65$ years able to respond to questions and stand up were included in the study based on availability. They were asked to describe their well-being from very bad to very good. The functional abilities were assessed by hand grip strength, the ability to stand up without assistance, the dependence on caregivers ( 1 - independent, 2 - partly dependent, 3 - fully dependent), the use of walking device assistance devices. Results: The home living seniors could stand up without assistance of hands more often than nursing home residents $(60.4 \%$ vs. $38.2 \%, p<0.001)$. The handgrip strength was higher in the elderly community-dwelling women $(0.3(0.2-0.3)$ vs. $0.2(0.15-0.2)$ $\mathrm{Ba}), p<0.001$. The nursing home residents were less often independent (62.8\% vs. $83.9 \%, p<0.001)$, more often partly dependent $(30.2 \%$ vs. $14.6 \%, p<0.001)$ and independent (7.0\% vs. $1.4 \%, p=0,001)$ while performing activities of daily living. The nursing home residents had higher walking device assistance needs (mean rank 345.7 vs. 219.2, $p<0.001$ ) and described their well-being as "good" more often $(28.4 \%$ vs. $16.8 \%$, $p=0.001)$ and less often as "bad" or "very bad" (18.9\% vs. $26.8 \%$, $p=0.048$ ). Conclusion. The subjective well-being of elderly nurse home residents is better than of home living seniors despite having less functional abilities.
\end{abstract}

Key words: well-being, functional abilities, elderly, hand grip strength, nursing home residents.

\section{Introduction}

The society in developed countries is aging. In Latvia, the mortality rate is higher (14.5/1000, $2016)$ than fertility rate $(11.2 / 1000,2016)$ and $19.6 \%$ of the population was $\geq 65$ years old in 2015 [1]. 150/10 000 of seniors live in nursing homes in Latvia (2015) [2]. The Eurostat expects that old-age dependency ratio will increase from $29 \%$ (2014) to $50 \%$ (2050) in the European Union (28) [4].

It is accepted that seniors prefer to remain in their homes because doing so allows them to maintain independence [5]. In Latvia, historically there has been a stigma over nursing homes indicating them as a "poorhouse" with shame and humiliation sense [6]. Elderly adapt more difficulty to new conditions [7], including new housing. In traditional culture, the elderly were cared by families. A qualitative study by Stepčenko A (2007) indicated that there is still stigmatization of gerontology institutions in Latvia, but it is slowly reducing [6]. In Latvia, the proportion of the institutionalized elderly aged $85(2-10 \%, 2011)$ is much lower than in 
more economically developed countries such as Sweden and Germany where the proportion of those living in an institutional household is 15-20\% [8].

A nursing home is defined as an establishment which accommodates chronically ill, usually frail, elderly persons and provides long-term nursing care, rehabilitation and other services [9].

The subjective well-being and subjective quality of life are virtually synonymous with each other [10]. Even if the subjective judgment is a distorted perception of reality, it is still valuable in perspective as it improves understanding how people perceive and report their word irrespective of their reasoning [11].

Studies have shown that well-being is highly affected by maintenance of independence in daily living activities [12], however, by the definition of nursing home, its residents should be more dependent in activities of daily living. Loss of independence in Activities of Daily Living (ADLs) is closely associated with institutionalization, caregiver burden [13]. Functional status affects the quality of life in old age [14]. Physical frailty may be used to define the population at high risk of disability onset or progression [15]. Hand grip strength is dependent on skeletal muscle mass and muscle function. It has been found to be a useful index for frailty [16].

The studies we found on nursing home residents in Latvia are scarce. The newest were dated 2007 [6, 17]. There have been no studies comparing nursing home and home living residents. The present study forms part of physical and social anthropology multicenter study, describing differences between nursing home and home living seniors.

The purpose of this study was to compare well-being and functional abilities between nursing home and home living seniors in Latvia. The second aim was to compare well-being and functional abilities in relation to age and gender in nursing home and home living seniors. In order to meet the objectives stated before following tasks were set. Firstly, the functional abilities i.e. the hand grip strength, dependence on care givers while performing activities of daily living and walking assistance needs in nursing home and home living seniors were described and compared between nursing home and home living seniors. Secondly, the wellbeing of the seniors was examined and compared between the groups. Next, the association between the well-being and functional abilities in nursing home and home living residents was analyzed. Finally, if the age and gender related to functional abilities and wellbeing in both groups of the seniors was examined.

\section{Material and methods}

\subsection{Selection and inclusion criteria}

The cross-sectional study was conducted from 2012 to 2014. The participants were approached at 11 nursing homes in Riga and regions of Latvia. All the residents who met the inclusion criteria were enrolled without undergoing randomization. The home living seniors were selected based on availability and approximate matching in terms of gender and sample size with nursing home residents. The home living sample was heterogeneous. The majority of them (72.1\%) were included in the study during their short-term admission at "Gerontology centre" of the Riga East University Hospital. The other home living seniors were involved in the study through associations of the retired.

The inclusion criteria were age $\geq 65$ years, the ability to stand up and stand still at least 2 minutes in order to make all anthropometric measurements and being able to answer questions. Assessment of the functional ability of seniors and responses to questions were recorded by two anthropology laboratory nurses. The study was approved by the Riga Stradins University Ethics Committee. The participants signed informed consent on the participation in the study. 
Table 1. Demographic data of the home and nursing home living seniors meeting the inclusion criteria.

\begin{tabular}{|l|c|c|c|c|}
\hline & $\begin{array}{c}\text { Home living } \\
\text { seniors } \\
(\mathbf{2 8 0 , 1 0 0 \% )}\end{array}$ & $\begin{array}{c}\text { Nursing home } \\
\text { residents } \\
(\mathbf{2 8 5}, \mathbf{1 0 0} \%)\end{array}$ & $\begin{array}{c}\text { Home and nursing } \\
\text { home living seniors } \\
(\mathbf{5 6 5}, \mathbf{1 0 0 \%})\end{array}$ & $\boldsymbol{p}$-value \\
\hline $\begin{array}{l}\text { Age, overall } \\
\text { (average } \pm \text { SD) }\end{array}$ & $77 \pm 6$ & $79 \pm 8$ & $78 \pm 8$ & $<0.001$ \\
\hline 64-74 years & $104(37.1 \%)$ & $90(31.6 \%)$ & $194(34.3 \%)$ & \\
\hline $75-84$ years & $135(48.2 \%)$ & $126(44.2 \%)$ & $261(46.2 \%)$ & \\
\hline 85 and more & $41(14.6 \%)$ & $69(24.2 \%)$ & $110(19.5 \%)$ & \\
\hline Gender & \multicolumn{5}{|l}{} \\
\hline Women & $220(22.8 \%)$ & $215(23.2 \%)$ & $435(23.0 \%)$ & 0.921 \\
\hline Men & $65(76.2 \%)$ & $65(77.2 \%)$ & $130(77.0 \%)$ & \\
\hline Settlement & \multicolumn{5}{|l}{} & \\
\hline Riga & $221(78.9 \%)$ & $157(55.1 \%)$ & $378(66.9 \%)$ & $<0.001$ \\
\hline Regions & $59(21.1 \%)$ & $128(44.9 \%)$ & $187(33.1 \%)$ & \\
\hline
\end{tabular}

\subsection{Variables analysed}

The residents were asked to describe their well-being from 1 (very bad) - 5 (very good). The functional abilities were assessed by hand grip strength measured by dynamometer "Dynatest" (maximal handgrip strength $1 \mathrm{Ba}$, precision $\pm 0.05 \mathrm{Ba}$ ), the ability to stand up ( 1 - no assistance needed, 2 - assistance is needed), the scale of walking device assistance needs ( 1 - no need of use, 2 - walking stick, 3 - standard and roller walkers, crutches, 4 wheelchair) and the ability to perform independently the activities of daily living (ADLs). It was assessed by nurses and expressed in three categories: 1 - fully able, 2 - partly able, 3 not able to perform ADLs without assistance. The handgrip strength was measured in both hands. In the case of difference between the left and the right side measurements, the largest ones were taken.

\subsection{Statistical analysis}

The Student-t-test was used to compare means between two independent samples with parametric data. The Mann Whitney $U$ test was performed to compare medians and distributions in two independent samples with non-parametric data. The Kruskal-Wallis $\mathrm{H}$ test was used in order to compare medians in three independent samples with non-parametric data. The Chi-Square and Fisher exact test to compare frequencies between groups. The Fisher exact test was used if cell frequencies were less than 5 . The data were analyzed by SPSS-22. The Chi-Square test and Fisher exact test were performed in online programme http://vassarstats.net/.

\section{Results}

\subsection{Baseline characteristics of the study population}

285 nursing homes residents and 280 home living seniors met the inclusion criteria. There were $77 \%$ of females and $33 \%$ males in both groups. The residents of nursing homes were a bit older (79 \pm 8 years) than those living at home (77 \pm 6 years), $t(563)=4,5, p<0.001$. The demographic data in detail is represented in Table 1. 


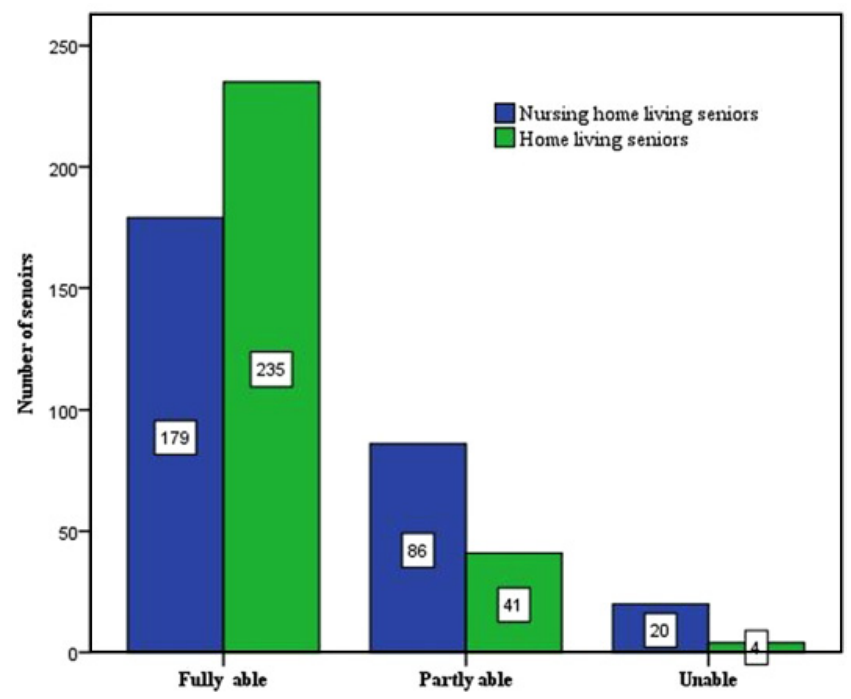

Fig. 1. The number of nursing home and home living seniors in relation to ability to perform activities of daily living without assistance.

Table 2. Walking assistance needs in nursing home and home living seniors.

\begin{tabular}{|l|c|c|c|c|c|}
\hline \multirow{2}{*}{} & & \multicolumn{3}{|c|}{ Type of walking assistance } & Total \\
\cline { 3 - 6 } & $\begin{array}{c}\text { Walks without } \\
\text { assistance }\end{array}$ & $\begin{array}{c}\text { Needs } \\
\text { walking } \\
\text { stick }\end{array}$ & $\begin{array}{c}\text { Standard or } \\
\text { roller } \\
\text { walkers }\end{array}$ & Wheelchair & \\
\hline $\begin{array}{c}\text { Nursing home } \\
\text { residents }\end{array}$ & $109(38.2 \%)$ & $78(27.4 \%)$ & $71(24.9 \%)$ & $27(9.5 \%)$ & $285(100.0 \%)$ \\
\hline $\begin{array}{l}\text { Home living } \\
\text { seniors }\end{array}$ & $22(78.9 \%)$ & $42(15.0 \%)$ & $17(6.1 \%)$ & $0(0.0 \%)$ & $280(100.0 \%)$ \\
\hline Total & 330 & 120 & 88 & 27 & 565 \\
\cline { 2 - 6 } & $58.4 \%$ & $21.2 \%$ & $15.6 \%$ & $4.8 \%$ & $100.0 \%$ \\
\hline
\end{tabular}

\subsection{Functional characteristics of nursing home and home living seniors}

Overall, the home living seniors had higher handgrip strength than those living in the nursing homes $(0.20(0.10-0.25)$ vs. $0.25(0.2-0.4) \mathrm{Ba}, U=26413.5, p<0.001)$. The home living seniors could stand up without assistance of hands more often than nursing home residents (170; $60.7 \%$ vs. $109 ; 38.2 \%, p<0.001)$.

The ability of the nursing home residents to perform activities of daily living (ADLs) is illustrated in Fig. 1. The nursing home residents could perform ADLs alone less often $(62.8 \%$ vs. $83.9 \%, p<0.001)$ and more often needed a partial assistance $(30.2 \%$ vs. $14.6 \%, p<0.001)$ and full assistance $(7.0 \%$ vs. $1.4 \%, p=0.001)$ than the home living seniors.

The nursing home residents had higher walking device assistance needs (mean rank 345.7 vs. $219.2, U=22043.0, p<0.001$ ). Walking assistance needs in detail are shown in Table 2. 


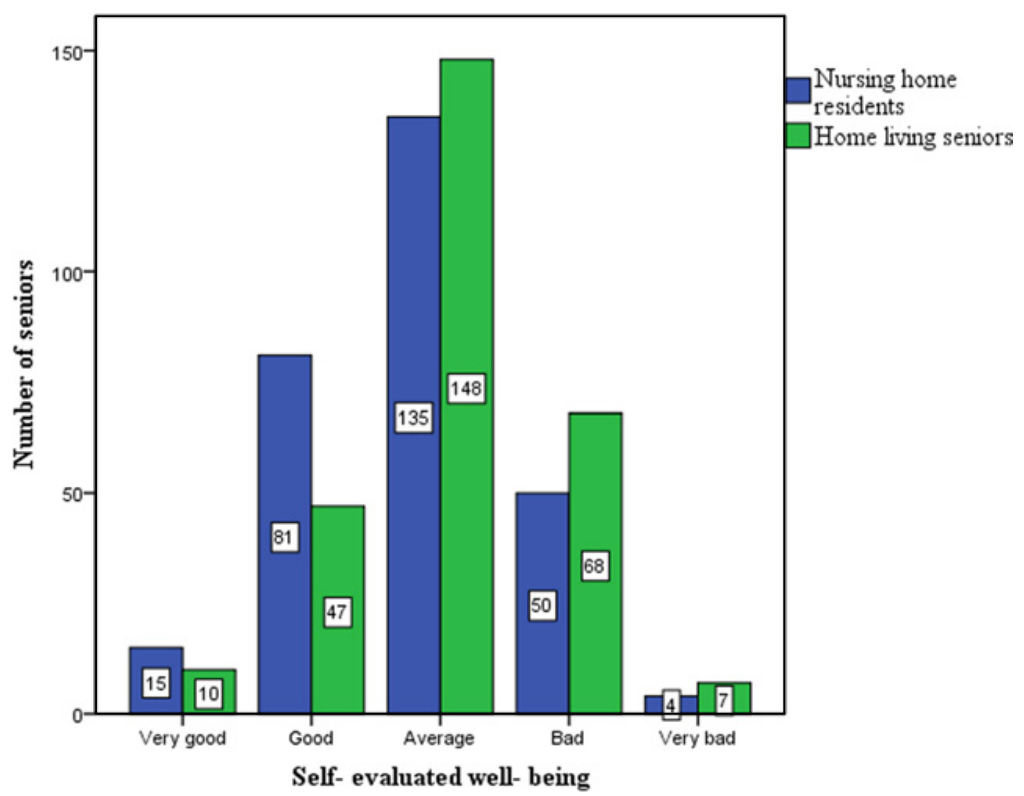

Fig. 2. Distribution of nursing home and home living seniors by level of well-being.

Table 3. Subjective well-being and ability to perform activities of daily living (ADLs) of seniors living at nursing home and home.

\begin{tabular}{|c|c|c|c|c|c|c|c|}
\hline & & \multicolumn{6}{|c|}{ Ability to perform ADLs without assistance } \\
\hline & & \multicolumn{2}{|c|}{ Fully able } & \multicolumn{2}{|c|}{ Partly able } & \multicolumn{2}{|c|}{ Unable } \\
\hline & & \begin{tabular}{|c|} 
Nursing \\
home \\
living seniors \\
seniors \\
\end{tabular} & $\begin{array}{c}\text { Home } \\
\text { living } \\
\text { seniors }\end{array}$ & \begin{tabular}{|c|}
$\begin{array}{c}\text { Nursing } \\
\text { home }\end{array}$ \\
living seniors \\
seniors
\end{tabular} & $\begin{array}{c}\text { Home } \\
\text { living } \\
\text { seniors }\end{array}$ & \begin{tabular}{|c|} 
Nursing \\
home \\
living \\
seniors \\
\end{tabular} & $\begin{array}{c}\text { Home } \\
\text { living } \\
\text { seniors }\end{array}$ \\
\hline \multirow[t]{5}{*}{$\begin{array}{l}\text { Subjective } \\
\text { well-being }\end{array}$} & $\begin{array}{l}\text { Very } \\
\text { good }\end{array}$ & $12(6.7 \%)$ & $8(3.4 \%)$ & $3(3.5 \%)$ & $1(2.4 \%)$ & $0(0.0 \%)$ & $1(25.0 \%)$ \\
\hline & Good & $65(36.5 \%)$ & $47(20.0 \%)$ & $12(14.0 \%)$ & $0(0 \%)$ & $4(20.0 \%)$ & $0(0.0 \%)$ \\
\hline & Average & $83(46.4 \%)$ & $134(57.0 \%)$ & $43(50.0 \%)$ & $12(29.3 \%)$ & $9(45.0 \%)$ & $2(50.0 \%)$ \\
\hline & \begin{tabular}{|c|} 
Bad or \\
very bad
\end{tabular} & $\begin{array}{c}19 \\
(10.6 \%) \\
\end{array}$ & $\begin{array}{c}46 \\
(19.6 \%) \\
\end{array}$ & $\begin{array}{c}28 \\
(32.6 \%) \\
\end{array}$ & $\begin{array}{c}28 \\
(68.3 \%) \\
\end{array}$ & $\begin{array}{c}7 \\
(35.0 \%) \\
\end{array}$ & $\begin{array}{c}1 \\
(25.0 \%) \\
\end{array}$ \\
\hline & Total & $179(100 \%)$ & $235(100 \%)$ & $86(100 \%)$ & $28(100 \%)$ & $20(100 \%)$ & $4(100 \%)$ \\
\hline
\end{tabular}

\subsection{Characteristics of well-being and its relation to ability to perform activities of daily living without assistance in nursing home and home living seniors}

Well-being was assessed on a 5-point scale. Majority of all participants assessed it as average, but there were differences among two groups of the study population. Figure 2 illustrates the well-being of nursing home and home living seniors. The nursing home residents described their well-being as "good" statistically significantly more often $(28.4 \%$ vs. $16.8 \%, p=0.001)$ and less often as "bad" or "very bad" $(18.9 \%$ vs. $26.8 \%, p=0.048)$ than the home living seniors. The "average" (47.4\% vs. $52.9 \%, p=0.207)$ and "very good" (5.3\% vs. $3.6 \%$, $p=0.414$ ) well-being did not differ between the groups.

A comparison of both well-being and ability to perform activities daily of living (ADLs) is shown in Table 3. The nursing home residents who needed a partial assistance with 
ADLs described their well-being more often as "average" (50.0\% vs. $29.3 \%, p=0.027)$ and "good" ( $14.0 \%$ vs. $0 \%, p=0.018)$ and less often as "bad" or "very bad" (32.6\% vs. $68.3 \%, p=0.0001)$. Those who could perform ADLs without assistance also reported their feeling more often as "good" $(36.3 \%$ vs. $20.0 \%, p=0.003)$ and less often as "bad" $(10.6 \%$ vs. $19.6 \%, p=0.019)$ compared to the same independence level group in home living seniors.

\subsection{Age as a factor influencing functional abilities and well-being}

The functional ability characteristics and subjective well-being in three age groups both in nursing home and home living seniors are represented in Table 4. All functional abilities- the ability to perform activities of daily living without assistance, ability to stand up from a sitting position on a chair, the needs for using mobility devices increased with age both in nursing home and home living seniors. Hand grip strength differed in age groups. See Table 5. The pair comparisons showed that there was a statistically significant difference between all age samples (age $\geq 85 \mathrm{y}$ and 75-84 y, $p=0.014,65-74 \mathrm{y}$ and 75-84 y, $p<0.001,65-74 \mathrm{y}$ and $\geq 85 \mathrm{y}, p<0.001)$ relating to the data shown in the Table 5 .

The handgrip strength differences in different age groups in nursing home and home living seniors are shown in Table 4. Regarding the nursing home residents, the statistically significant differences were obtained between age groups 65-74 y and 75-85 y, $p=0.031$ and $65-74 \mathrm{y}$ and $\geq 85 \mathrm{y}, p=0.001$. Similarly, in relation to home living seniors, the statistically significant differences were obtained between age groups $65-74 \mathrm{y}$ and $75-85 \mathrm{y}$, $p=0.004$ and $65-74 \mathrm{y}$ and $\geq 85 \mathrm{y}, p=0.007$.

There were no differences in well-being between the age groups $65-74,75-85, \geq 85$ years when the data was not split in nursing home and home living seniors, $p=0.215$. The home living seniors aged 75-84 y described their well-being as "good" statistically significantly less often $(11.9 \%$ vs. $26.9 \%, p=0.0029)$ and more often as "average" (58.5\% vs. $47.1 \%$, $p=0.035$ ) than those aged $65-74 \mathrm{y}$. In contrast, regarding nursing home residents, no differences in well-being described as "good" between age groups 65-74 y (33.3\%) and $75-84$ y $(24.6 \%)$ were found, $p=0.164$. The well-being described as "good" between age groups $75-84 \mathrm{y}$ and $\geq 85 \mathrm{y}$ did not differ in both nursing home ( $24.6 \%$ vs. $28.4 \%, p=0.825$ ) and home living seniors (11.9\% vs. $7.3 \%, p=0.34$ ) also. Similarly, the well-being described as "average" between age groups $75-84 \mathrm{y}$ and $\geq 85 \mathrm{y}$ did not differ in both nursing home ( $49.2 \%$ vs. $49.3 \%, p=0.585)$ and home living seniors (58.5\% vs. $48.8 \% p=0.049)$. In the nursing homes the well-being described as "bad" or "very bad" did not differ between the age groups. In contrast, the home living seniors aged $\geq 85$ described their "well-being" more often as "bad"/ "very bad" than those aged $65-74$ y (39.0\% vs. $26.6 \%, p=0.025)$, but not $74-84$ y (39.0\% vs. $22.2 \%, p=0.335)$.

\subsection{Gender as a factor influencing functional abilities and well-being}

In relation to gender, some functional abilities differed between men and women. The hand grip strength was higher in men $(0.40(0.30-0.50), \mathrm{Ba})$ than in women $(0.20(0.10-0.15)$, $\mathrm{Ba}), U=9674.5, p<0.001$ and when the data was split in nursing home and home living seniors. Women living in nursing homes had lower handgrip strength than those living at home. The nursing home and home living men's hand grip strength differed less - there was no difference in medians (Table 2), however, the distribution of hand grip strength differed significantly, showing higher mean rank in home living seniors than those living at nursing home (mean rank 78.84 vs. $57.04, U=2589.5, p=0.016$ ). See Table 6. 


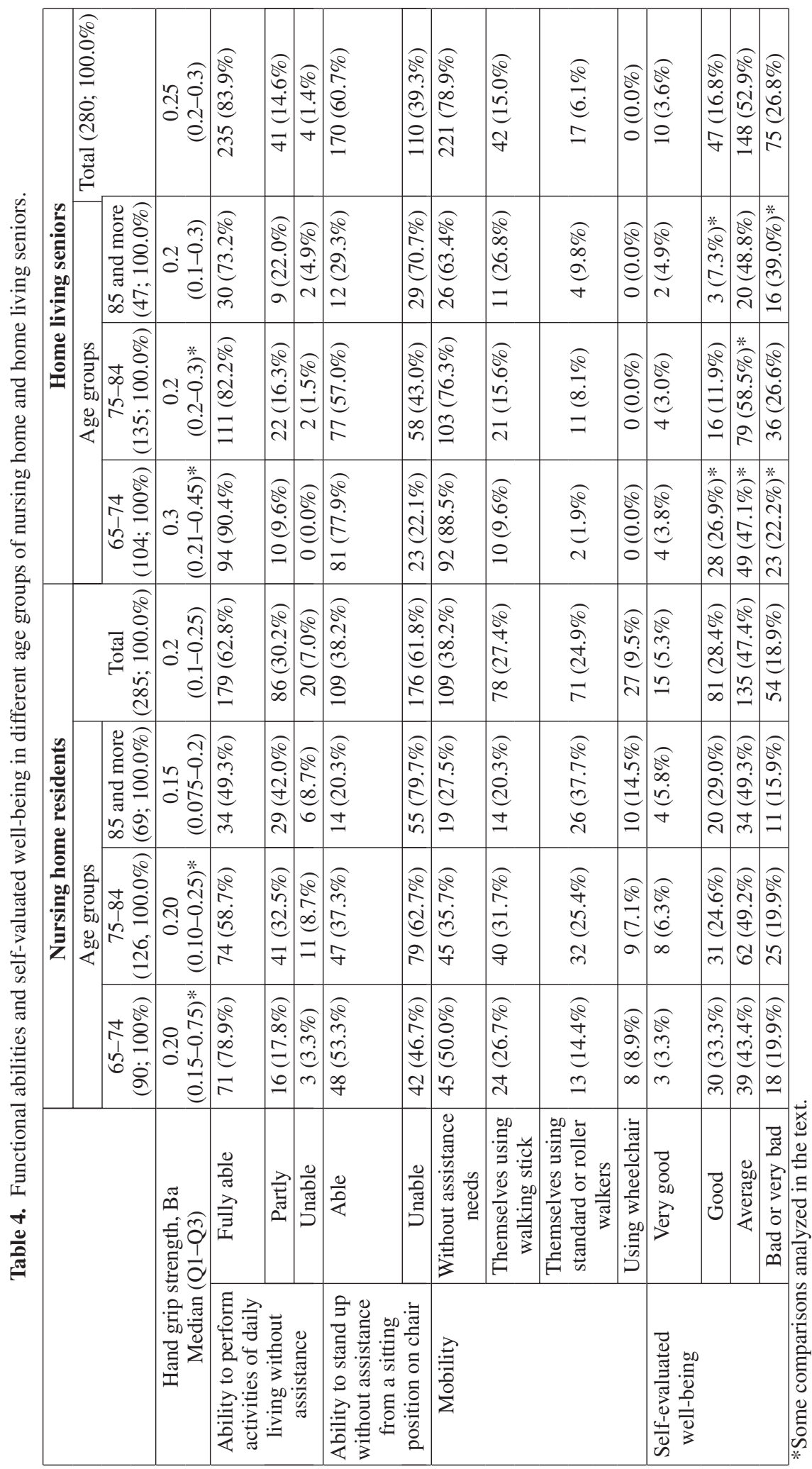


Table 5. Hand grip strength of both nursing home and home living seniors in relation to age.

\begin{tabular}{|c|c|c|c|c|}
\hline Age, years & $\mathbf{6 5 - 7 4}$ & $\mathbf{7 5 - 8 4}$ & $\mathbf{8 5}$ and more & $\boldsymbol{p}$-value \\
\hline $\begin{array}{c}\text { Hand grip strength, Ba } \\
\text { Median (Q1-Q3) }\end{array}$ & $0.30(0.02-0.40)$ & $0.25(0.15-0.30)$ & $0.15(0.10-0.20)$ & 0.014 \\
\hline
\end{tabular}

Table 6. Hand grip strength in nursing home and home living seniors depending on gender.

\begin{tabular}{|c|c|c|c|}
\hline $\begin{array}{c}\text { Handgrip } \\
\text { strength }\end{array}$ & $\begin{array}{c}\text { Nursing home living } \\
\text { seniors (median, } \\
\text { interquartile } \\
\text { range), Ba }\end{array}$ & $\begin{array}{c}\text { Home living seniors } \\
\text { (median, } \\
\text { interquartile } \\
\text { range), Ba }\end{array}$ & $\boldsymbol{p}$-value \\
\hline Men & $0.4(0.25-0.45)$ & $0.4(0.3-0.6)$ & 0.178 \\
\hline Women & $0.2(0.15-0.25)$ & $0.3(0.2-0.3)$ & $p<0.001$ \\
\hline$p$-value & $<0.001$ & $<0.001$ & \\
\hline
\end{tabular}

The men could stand up without assistance more often than women (60.8\% vs. $46.0 \%)$, $p=0.004$ overall; when divided in nursing home and home living seniors, the statistically significant results were obtained only in home living seniors (73.8\% vs. 56.7\%, $p=0.013)$, but not in nursing home seniors $(47.7 \%$ vs. $35.5 \%, p=0.074)$. The ability to perform activities of daily living did not differ between men and women both in general $(p=0.172)$ and nursing home $(p=0.428)$ and home living seniors $(p=0.307)$. The corresponding data are shown in the Table 7.

The men could move around without assistance more often than women both in general $(70.8 \%$ vs. $54.7 \%, p=0.002)$ and nursing home and home living seniors. They used less often walkers or rollers $(6.9 \%$ vs. $18.2 \%, p=0.002)$. No home living seniors requiring a wheelchair were observed in the study, as well as no men using rollers or walkers were observed in the study (Table 7).

Regarding ability to perform activities of daily living (ADLs) without assistance there was no statistically siginificant difference between men and women, $p=0.172$. Also when the performance was analyzed in male and female nursing home and home living seniors no differences were observed, $p=0.428$.

The well-being did not differ in terms of gender both in general $(p=0.640)$ and in nursing home $(p=0.308)$ and home living seniors $(p=0.641)$. The data are shown in Table 8 .

\section{Discussion}

The study aimed to compare well-being and functional abilities between nursing home and home living Latvian seniors. To the best of our knowledge, no similar studies comparing the subjective perception of well-being and functional abilities of nursing home and home living seniors are available.

The present study showed that ability to perform activities of daily living was lower in nursing home residents than in community-dwelling seniors. A study from Finland supports the result. It reported that home care receiving individuals had approximately twice lower ADL score than those living long-term in nursing homes [18]. In general, the finding is in accordance with the definition of a nursing home. The 28th point of The Social Service and aid law of Latvia (2002) states that rights of care in nursing home belong to its residents in the age of retirement and those with eyesight or physical disability if the amount of social service needed exceeds the amount of social service in day-care or home care available [19]. Approximately a third part of nursing homes admitted that they do not need walking 
Table 7. Functional abilities in relation to gender in nursing home and home living seniors.

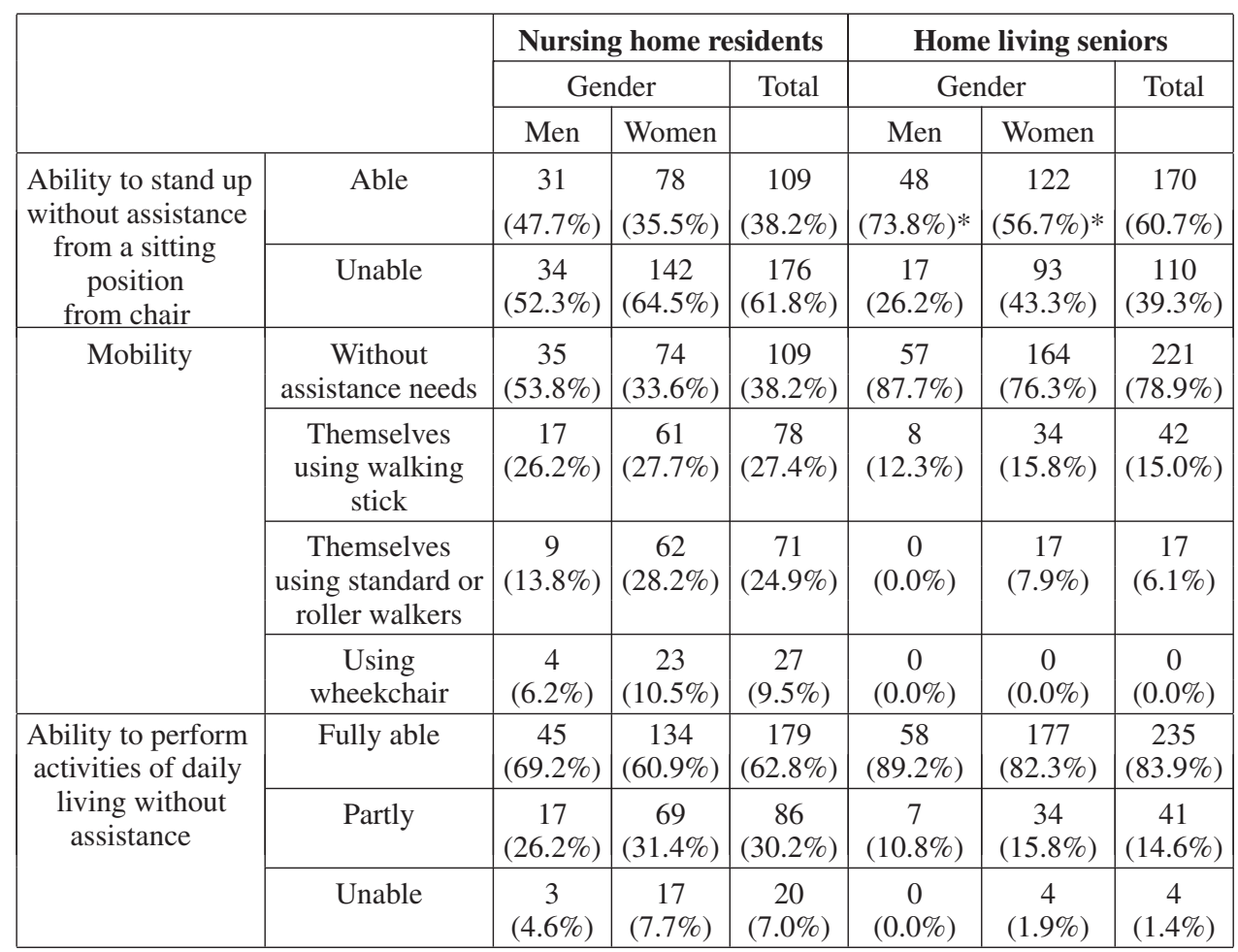

Table 8. Well-being in relation to gender in nursing home and home living seniors.

\begin{tabular}{|c|c|c|c|c|c|c|c|}
\hline & & \multicolumn{3}{|c|}{ Nursing home residents } & \multicolumn{3}{|c|}{ Home living seniors } \\
\hline & & \multicolumn{2}{|c|}{ Gender } & \multirow[t]{2}{*}{ Total } & \multicolumn{2}{|c|}{ Gender } & \multirow[t]{2}{*}{ Total } \\
\hline & & Men & Women & & Men & Women & \\
\hline \multirow[t]{5}{*}{$\begin{array}{l}\text { Self-evaluated } \\
\text { well-being }\end{array}$} & Very good & $\begin{array}{c}3 \\
(4.6 \%) \\
\end{array}$ & $\begin{array}{c}12 \\
(5.5 \%) \\
\end{array}$ & $\begin{array}{c}15 \\
(5.3 \%) \\
\end{array}$ & $\begin{array}{c}2 \\
(3.1 \%) \\
\end{array}$ & $\begin{array}{c}8 \\
(3.7 \%) \\
\end{array}$ & $\begin{array}{c}10 \\
(3.6 \%)\end{array}$ \\
\hline & Good & $\begin{array}{c}23 \\
(35.4 \%)\end{array}$ & $\begin{array}{c}58 \\
(26.4 \%)\end{array}$ & $\begin{array}{c}81 \\
(28.4 \%) \\
\end{array}$ & $\begin{array}{c}11 \\
(16.9 \%)\end{array}$ & $\begin{array}{c}36 \\
(16.7 \%)\end{array}$ & $\begin{array}{c}47 \\
(16.8 \%)\end{array}$ \\
\hline & Average & $\begin{array}{c}26 \\
(40.0 \%) \\
\end{array}$ & $\begin{array}{c}109 \\
(49.5 \%) \\
\end{array}$ & $\begin{array}{c}135 \\
(47.4 \%) \\
\end{array}$ & $\begin{array}{c}41 \\
(63.1 \%) \\
\end{array}$ & $\begin{array}{c}107 \\
(49.8 \%) \\
\end{array}$ & $\begin{array}{c}148 \\
(52.9 \%) \\
\end{array}$ \\
\hline & $\mathrm{Bad}$ & $\begin{array}{c}12 \\
(18.5 \%) \\
\end{array}$ & $\begin{array}{c}38 \\
(17.3 \%) \\
\end{array}$ & $\begin{array}{c}50 \\
(17.5 \%) \\
\end{array}$ & $\begin{array}{c}10 \\
(15.4 \%) \\
\end{array}$ & $\begin{array}{c}58 \\
(27.0 \%) \\
\end{array}$ & $\begin{array}{c}68 \\
(24.3 \%) \\
\end{array}$ \\
\hline & Very bad & $\begin{array}{c}1 \\
(1.5 \%)\end{array}$ & $\begin{array}{c}3 \\
(1.4 \%)\end{array}$ & $\begin{array}{c}4 \\
(1.4 \%)\end{array}$ & $\begin{array}{c}1 \\
(1.5 \%)\end{array}$ & $\begin{array}{c}6 \\
(2.8 \%)\end{array}$ & $\begin{array}{c}7 \\
(2.5 \%)\end{array}$ \\
\hline
\end{tabular}

assistance (38.2\%) and assistance in daily living activities (31.7\%), so the question of their consistency to the point of law mentioned above arises. However, the responses were subjective, and cognitive function of the nursing home residents was not assessed. Cognitive impairment is one of the main reasons for being admitted to a nursing home [20]. Because of the inclusion criteria (ability to respond to questions, stand up and stand for 2 minutes), only the best functioning part of nursing home residents was assessed.

The ability to perform activities of daily living has been closely linked to the well-being. However, the authors' study showed that nursing home living seniors with partial or no needs of assistance to perform ADLs reported to have more often "good" and less often "bad or 
very bad" well-being than home living seniors. It is alarming that two thirds of home living seniors with partial assistance needs described their well-being as "bad" or "very bad". The availability of assistance in activities of daily living home living seniors was not assessed. In Spain [21] 14\% of subjects reported dependency for daily activities. Of these, $40 \%$ reported receiving inadequate assistance. In our study, $16 \%$ of community-dwelling seniors reported dependency for daily activities. Another important factor to consider is usability of housing. The ENABLE-AGE study conducted also in Latvia showed that the perceived usability of housing in activity and environmental aspects was lower in those community-dwelling seniors who were dependent in activities of daily living [22]. The well-being is a complex concept and other its determinants as absence of pain and suffering, social support, financial stability, a sense of usefulness to others [9] should be assessed. It is possible that a better well-being in nursing home residents may be explained by larger social contacts, involvement of seniors in various leisure activities and in different programs or voluntary activities [12].

A recent study based on data from the European project "Enabling Autonomy, Participation, and Well-Being in Old Age" demonstrated that the Latvian communitydwelling elderly women aged 74-80 years had an average life satisfaction (median 5 assessed using a scale from 0 up to 10) similarly to the authors' study, and the variance of life satisfaction was explained mostly by coping factors such as fight, distraction, followed by standards of living and less by health [23].

Concerning age and well-being, the authors' study indicated that well-being decreased in home living seniors aged 85 and more in comparison with those aged 65-74 y and statistically insignificantly in comparison with those aged 75-84. In contrast, a recent longitudinal 9-yearstudy in Latvia showed that life satisfaction increased in those aged 85 over the years even though objective health factors decreased. It must be noted that there was a high dropout rate reaching $80.2 \%$ from the study because of the institutionalization or death of the home living seniors [24].

The handgrip strength was higher both in men than in women. It is supported by other studies $[8,25]$. Those women who lived in nursing homes had lower handgrip strength than home living ones. Higher hand grip strength in community-dwelling seniors than nursing home residents has been also reported in the study by Roberts [25].

The ability to perform daily tasks independently reduced with age. The same trend was demonstrated in a large retrospective Italian Study in which the source of information was geriatric electronic forms completed by general practitioner [26]. The proportion of the independent community-dwelling seniors in the Italian study was $97.1 \%$ and $81.3 \%$ and $63.8 \%$ accordingly to the age groups $65-74 \mathrm{y}, 75-84 \mathrm{y}$, and $\geq 85 \mathrm{y}$. There were less independent community-dwelling seniors in the authors' study in comparison with the Italian study in the age group of 65-74 y (90.4\%), approximately the same in the age group $75-84 \mathrm{y}(82.2 \%)$ and more in the age group of $\geq 85 \mathrm{y}(73.2 \%)$. However, the Barthel index, another method to assess the independence of the caregiver was used in the Italian study.

Other functional abilities such as standing up without assistance and need to use walking assistance devices and hand grip strength also reduced with age. Similar findings - lower grip strength and reduced mobility - were found in the study of nursing home residents in Nordic countries [9]. The muscle strength decreases at an approximate rate of 12\%-14\% per decade after age 50 [27].

Authors' study did not indicate that the gender affected the ability of the seniors to perform activities of daily living without assistance. In contrast, in a large population study in Finland, it was found that women had a bit lower performance of ADLs than men both in nursing home and home living seniors [18]. However, the authors' study showed that men were more often able to stand up without assistance and had greater handgrip strength than 
women. A similar trend-higher ability to perform physical activities and greater grip strength has been shown in the meta-analysis by Cooper [28].

This is the first study to compare well-being in nursing home and community-dwelling seniors. The study assesses the subjective perception of well-being and ability to perform daily activities of living. Paradoxically, the lesser ability to perform ADLs did not affect well-being of nursing home living residents in contrast to home living seniors. It might be explained by inadequacy of social and nursing care in home living seniors, however, other possibilities like fear of criticising the nursing home, lower standards for feeling well, should be considered.

The limitations of the study are lack of randomization during selection, selection by availability, and that no scales were used to assess more precisely the functional abilities and well-being of seniors. It was not detected with precision if those who required assistance in ADLs and lived at home received sufficient care and its source.

It would be useful to study the availability of home care in community-dwelling seniors as it may explain partly why they reported their well-being more often as bad or very bad than nursing home residents and it is a modifiable factor provided by the social service of local councils. The role of other less modifiable determinants of well-being of seniors should be investigated.

\section{Conclusions}

The subjective well-being of elderly nurse home residents is better than of home living seniors despite having less functional abilities. Two thirds of home living seniors with partial assistance needs reported "bad or very bad" well-being. Larger studies with randomized selection should be performed to other factors influencing of well-being in elderly.

\section{References}

[1] Calculations based on data available at Central Bureau of Statistics (Latvijas Centrālā Statistikas pārvalde):

- Mortality http://data.csb.gov.lv/pxweb/lv/Sociala/Sociala_ikgad_iedz_ mirst/IMG010 . px/table/tableViewLayout2/?rxid=562c2205-ba57-4130b63a-6991f49ab6fe

[2] http://data.csb.gov.lv/pxweb/lv/Sociala/Sociala_ikgad_iedz_ iedzskaits/IS0020 px/table/tableViewLayout2/?rxid=562c2205-ba574130-b63a-6991f49ab6fe

- Fertility http://data.csb.gov.lv/pxweb/lv/Sociala/Sociala_ikgad_iedz_ dzimst/ID0010.px/table/tableViewLayout2/?rxid=562c2205-ba57-4130b63a-6991f49ab6fe

http://data.csb.gov.lv/pxweb/lv/Sociala/Sociala_ikgad_iedz_ iedzskaits/IS0020 px/table/tableViewLayout2/?rxid=562c2205-ba574130-b63a-6991f49ab6fe

- More than $>65$ y old http://data.csb.gov.lv/pxweb/lv/Sociala/Sociala_ikgad_iedz_ iedzskaits/IS0022.px/table/tableViewLayout2/?rxid=562c2205-ba574130-b63a-6991f49ab6fe 
[3] Web page of Latvian Ministry of Welfare, section Galvenie rādītāji http://www . lm.gov.1v/text/3684

[4] http://ec.europa.eu/eurostat/statistics-explained/index.php/

People_in_the_EU_\%E2\%80\%93_population_projections

[5] H.H Ewen, T.R. Washington, K.G. Emerson, A.T. Carswell, M.L. Smith, Int. J. Environ. Res. Public. Health 14 (2017)

[6] A. Stepčenko, Latvijas Univeristātes raksti 714, 54 (2007)

[7] A. Slokenberga, D. Zepa. Vecums, liktenis, izaicinājums (Rīgas Austrumu klīniskās universitātes slimnīcas Atbalsta fonds, Rīga, 2013)

[8] http://ec.europa.eu/eurostat/statisticsexplained/index.php/People_ in_the_EU_\% $2 \% 80 \% 93$ _statistics_on_an_ageing_society

[9] H. Grönstedt, K. Hellström, A. Bergland, J.L. Helbostad et al. Aging Clinical Exper. Res. 23, 413 (2011)

[10] L. Camfield, S.M. Skevington, J. Health Psychol. 13, 764 (2008)

[11] D.A. Clark, Vision of development: A study of human values (Edward Elgar, the United Kingdom, 2000)

[12] M. Sováriová Soósová, Eur. J. Nurs. Midw. 7, 484 (2016)

[13] K.E. Covinsky, R.M. Palmer, R.H. Fortinsky, S.R. Counsell, A.L. Stewart et al., J. Amer. Geriat. Soc. 51, 451 (2003)

[14] J. Elisabeth, Health Sci. J. 1, 3 (2007)

[15] L. Ferrucci, J.M. Guralnik, S. Studenski, L.P. Fried, J. Am. Geriatrics Soc. 52, 625-634 (2004)

[16] N. Kamide, R. Kamiya, T. Nakazono, M. Ando, Environ. Health Prev. Med. 20, 441-446 (2015)

[17] A. Stepčenko, M. Brants, L. Bukovska, Dzīves kvalitāte Latvijas veco ïaužu pansionātos (LU Akadēmiskais apgāds, Rīga, 2007)

[18] P. Laukkanen, P. Karppi, E. Heikkinen, M. Kauppinen, Age and Ageing 30, 489-494 (2001)

[19] https://likumi.lv/doc.php?id=68488

[20] M. Luppa, T. Luck, S. Weyerer, H.H. König, E. Brähler, S.G. Riedel-Heller, A Syst. Rev. Age and Ageing 39, 31-38 (2010)

[21] A. Otero, M.J. G. Yébenes, A. Rodríguez-Laso, M.V. Zunzunegui, Aging Clin. Exper. Res. 15, 234 (2003)

[22] S. Tomsone, V. Horstmann, F. Oswald, S. Iwarsson, Aging Clin. Exper. Res. 25, 317-328 (2013)

[23] V. Horstmann, M. Haak, S. Tomsone, S. Iwarsson, A. Gräsbeck, A. J. Cross-Cultural Gerontology 27, 391 (2012)

[24] C. Löfquist, S. Tomsone, S. Iwarsson, V. Horstmann, Haak, J. Cross-Cultural Gerontology 32, 17-29 (2017)

[25] H.C. Roberts, H. Syddall, J. Butchart, J. Sparkes et al., Age and Ageing 43, 241-246 (2014)

[26] F. Guerriero, V. Orlando, D.U. Tari, A. Di Giorgio et al., Trans. Med. @ UniSa 13, 59-64 (2016)

[27] B.F. Hurley, S.M. Roth, Sports Med. (Auckland, N.Z.) 30, 249-268 (2000)

[28] R. Cooper, R. Hardy, A.A. Sayer, Y. Ben-Shlomo et al., PLoS ONE 6(11), e27899 (2011) 